\title{
COMPARATIVE STUDY ON THE DISPLACEMENT OF METHYLENE BLUE FROM AQUEOUS SOLUTION USING AGRICULTURAL WASTE ACTIVATED CARBON AND ACTIVATED CARBON + $\mathrm{Fe}_{3} \mathrm{O}_{4}$ NANOCOMPOSITE
}

\author{
S. Sivaprakash ${ }^{1}$ and S.K. Krishna ${ }^{2}$ \\ ${ }^{1}$ Department of Chemistry, Builders Engineering College, Kangayam \\ ${ }^{2}$ Department of Chemistry, Chikkaiah Naicker College, Erode \\ *E-mail: sivaebet@gmail.com
}

\begin{abstract}
The present study deals with the adsorption property of cajanus cajan stem activated carbon (CCAC) and cajanus cajan stem activated carbon (CCAC) + Fe3O4 Nanocomposite. The main aim of the study is to give aid to the dying industries in the removal of toxic dyes from the effluent of the dyeing industry at a low cost. To remove Methylene Blue dye from aqueous solution, the adsorbents CCAC and CCAC+Fe3O4 Nanocomposite were used. The results showed that the nanocomposite was better than CCAC.
\end{abstract}

Keywords: Activated Carbon, Adsorbent, Composite, Dye, Capacity.

(C) RASĀYAN. All rights reserved

\section{INTRODUCTION}

Activated carbon from agricultural waste material was introduced industrially in the first part of this century and used in sugar refining. In the dying industries activated carbon from black ash was found very effective in decolorizing liquids. ${ }^{1}$ The purification of the factory outflow is an important part of environmental science. In recent years the importance of pollution control becomes increasing. Various dyes are applied in many industrial works, such as printing, dyeing, etc. Although industrial dyes are not only toxic, it can develop a few abnormal problems like high heartbeat rate, jaundice and nervous system problems in human body. ${ }^{2}$ Nowadays printing and dyeing related factories are in critical situation due to the treatment of dye waste which is not easy in economical limitation. ${ }^{3}$ Presently many numbers of treatment processes are available for displacement of dye from dyeing effluent. The important and economically better method is adsorption process. For adsorption process usage of commercial activated carbon is costly. However the researchers are in a position of investigating cheap and best-activated carbon to remove dyes from wastewater. ${ }^{4}$ Further the utilization of nanoparticles for displacement of impurities from wastewater is good and new method. Nano methodology commonly studied in view of various applications. ${ }^{5}$ Nanoparticles of Iron oxide play an important role in many researches ${ }^{6}$. In few magnetic Nanoparticles, $\mathrm{Fe}_{3} \mathrm{O}_{4}$ is an important one. ${ }^{7,8}$ The different ways are used to prepare $\mathrm{Fe} 3 \mathrm{O} 4$ Nanomaterials. Furthermore, the addition of iron oxide ( $\mathrm{Fe} 3 \mathrm{O} 4)$ develops the chemical properties and recyclability of adsorbent. In this study, CCAC prepared by physical method and $\mathrm{CCAC}-\mathrm{Fe}_{3} \mathrm{O}_{4}$ nanocomposite were prepared by hydrothermal method. The resulting $\mathrm{CCAC}$ and $\mathrm{CCAC}-\mathrm{Fe}_{3} \mathrm{O}_{4}$ nanocomposite were characterized by XRD and FTIR. ${ }^{9}$ In this study nanoparticles of $\mathrm{Fe}_{3} \mathrm{O}_{4}$ supported on cajanus cajan stem activated carbon (AC). ${ }^{10}$ The present research investigates the related characteristic study of obtained CCAC and $\mathrm{CCAC}-\mathrm{Fe}_{3} \mathrm{O}_{4}$ nanocomposite. It will be used as a cheap and effective adsorbent in the adsorption of Methylene Blue (MB). ${ }^{11}$

\section{Adsorbents}

\section{EXPERIMENTAL}

Cajanus cajan is the most important grain legume agricultural crop in semi-arid tropics. As it contains a Rasayan J. Chem., 12(4), 2166-2175(2019)

http://dx.doi.org/10.31788/RJC.2019.1245181

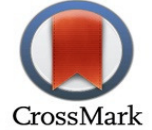




\section{RASĀYAN J. Chem.}

Vol. 12 | No. 4 |2166 - 2175| October - December | 2019

high level of proteins and amino acids like methionine, lysine and tryptophane it is used as a food as well as a cover/forage crop. It is a member of the fabaceae family. Commonly it is also known as red gram, congo pea, gungo pea and no eye pea. ${ }^{12}$

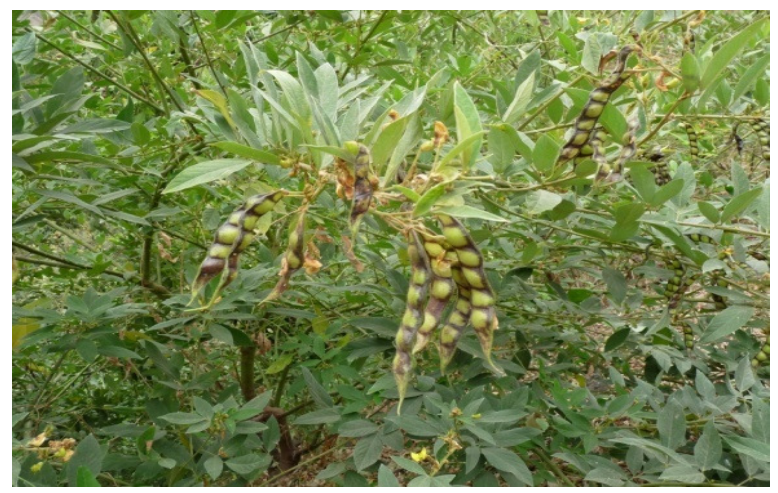

Fig.-1:Cajanus cajan Plant

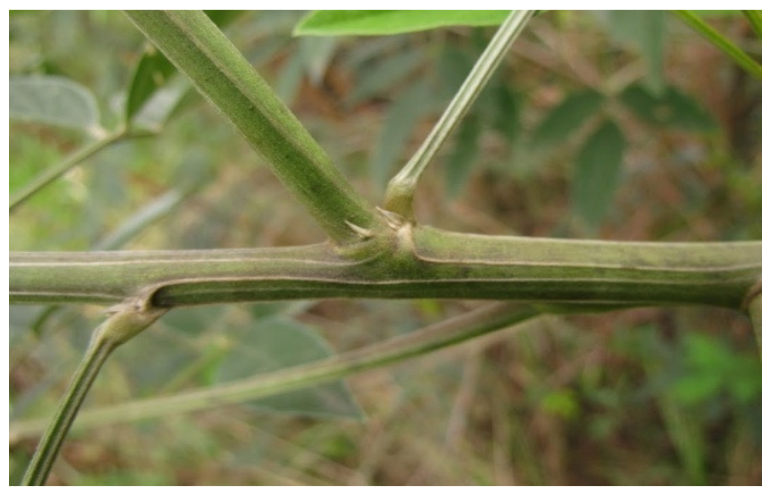

Fig.-2:Cajanus cajan Green Stem

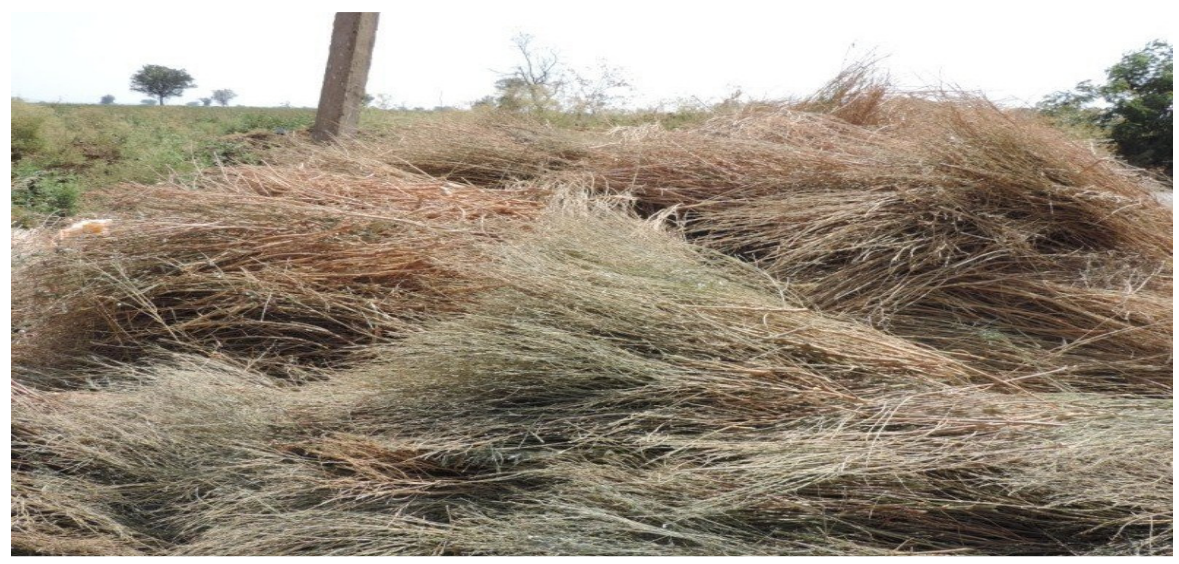

Fig.-3:Cajanus cajan Dry Stem

\section{Preparation of Activated Carbon (CCAC) by Physical Method}

The stems of Cajanus cajan, available in plenty, were handpicked from a place in Erode District, Tamil Nadu, South India and washed with distilled water several times. The material, cut into pieces of size 20$40 \mathrm{~mm}$, was dried in direct sunlight for 10 days. The dried mass was used for the preparation of adsorbent as per the following procedure.

The dried samples of Cajanus cajan stems were placed in a muffle furnace and heated at $800^{\circ} \mathrm{C}$ for two hours. The material was allowed to cool and cleaned using distilled water repeatedly and then dried in a hot air oven at $105^{\circ} \mathrm{C}$ for four hours and grounded.

The mass obtained was sieved with a $53 \mu$ mesh to get a finely powdered Cajanus cajan stem activated carbon (CCAC) and the same was stored in the container and later used.

\section{Synthesis of Nano Composites $\left(\mathrm{CCAC}-\mathrm{Fe}_{3} \mathrm{O}_{4}\right)$ by Hydrothermal Method}

The hydrothermal method is carried out by the water-based method at a minimum temperature range of 160$220^{\circ} \mathrm{C}$ in an eco-friendly procedure. It is a very effective process of preparing nanocomposite materials. ${ }^{14}$ The activated carbon- $\mathrm{Fe}_{3} \mathrm{O}_{4}$ nanocomposite was prepared by utilizing this method.

In a typical experiment, $50 \mathrm{mg}$ of Cajanus cajan stem activated carbon was suspended in $50 \mathrm{~mL}$ of deionized water. Subsequently, $30 \mathrm{~mL}$ of $\mathrm{FeCl}_{2} \cdot 4 \mathrm{H}_{2} \mathrm{O}$ and $80 \mathrm{~mL}$ of $\mathrm{FeCl}_{3} \cdot 6 \mathrm{H}_{2} \mathrm{O}$ were added into the above solution and $\mathrm{p}^{\mathrm{H}}$ was adjusted to $10-11$ by adding $30 \%$ of ammonium hydroxide solution. After that, the final solution was shifted to the $100 \mathrm{ml}$ autoclave with inner coated Teflon maintained at $180^{\circ} \mathrm{C}$ for 12 hours. Then the autoclave was cooled to normal temperature and the black precipitate obtained was washed by using double distilled water and ethanol several times. Finally, the prepared $\mathrm{Fe}_{3} \mathrm{O}_{4}+$ Cajanus 
cajan stem activated carbon nanocomposite $\left(\mathrm{CCAC}+\mathrm{Fe}_{3} \mathrm{O}_{4}\right)$ sample was kept overnight in a vacuum oven at $70^{\circ} \mathrm{C}$.

\section{Characterization of the Adsorbents}

The physicochemical characteristics of the adsorbents, CCAC and CCAC- $\mathrm{Fe}_{3} \mathrm{O}_{4}$ Nanocomposite, are determined using the standard procedures and through XRD, FTIR and SEM. The obtained results from the characteristic study confirmed the formation of activated carbon and nanocomposite.

Adsorbate

Methylene Blue (MB), Swiss blue

C.I.: 52015, Molecular formula : $\mathrm{C}_{16} \mathrm{H}_{18} \mathrm{ClN}_{3} \mathrm{~S}$, Molecular weight: $319.9 \mathrm{~g} / \mathrm{mol}$, M.P.:100 - $110^{0} \mathrm{C}$

(decompose), $\lambda \max : 665 \mathrm{~nm}$.

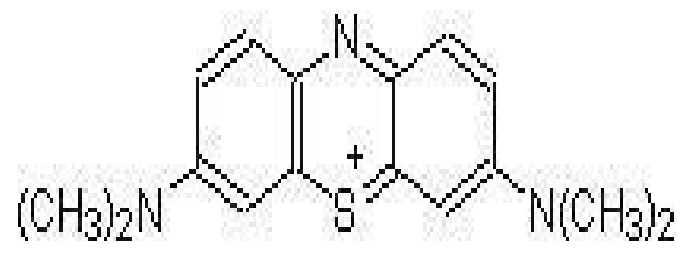

Fig.-4: Methylene Blue

Methylene Blue (MB), is mostly utilized for coloring paper, cotton, wool, nylon, silk, acrylic and so on. It can cause the burning of eyes and lead to damage to the eyes. On inhalation of this dye difficulty like increase in heartbeat, in breathing, vomiting, diarrohea, jaundice, quadriplegia and tissue nercosis and nausea are caused in human beings.

\section{Consequence of the Concentration of Dye}

\section{RESULTS AND DISCUSSION}

Displacement tests were started and continued at $301 \mathrm{~K}$ to compare the relative efficiencies of CCAC$\mathrm{Fe}_{3} \mathrm{O}_{4}$ nanocomposite and CCAC obtained from the stems of the plant Cajanus cajan in removing the basic dye MB. To identify the influence of contact time and concentration of MB dye, 50mL of dye solutions is added with a known weight of adsorbents $(100 \mathrm{mg} / 50 \mathrm{~mL})$ at various concentrations of dye (10$40 \mathrm{mg} / \mathrm{L}$ ) in $100 \mathrm{~mL}$ conical flasks which were shaken at $120 \mathrm{rpm}$ for predetermined time interval in a thermostated mechanical shaker. The adsorbate and adsorbent are separated by centrifugation. The absorbance of the MB dye solutions was analyzed by spectrophotometer in the respective $\lambda_{\max }$ values.

The adsorption of $\mathrm{MB}$ dye on both $\mathrm{CCAC}-\mathrm{Fe}_{3} \mathrm{O}_{4}$ nanocomposite and CCAC adsorbents at different initial concentrations was shown in Tables-1, 2 and Figs.-5 and 6. From the obtained data, it can be noted that both the percentage of color removal and displacement character increased with increase in initial concentration of the dye. When the $\mathrm{CCAC}-\mathrm{Fe}_{3} \mathrm{O}_{4}$ nanocomposite was the adsorbent, the amount of removal at equilibrium was attained to raise from $81.56 \%$ to $93.34 \%$ as the beginning concentration of dye was raised from $10 \mathrm{mg} / \mathrm{L}$ to $40 \mathrm{mg} / \mathrm{L}$. Similarly with CCAC as the adsorbent, the percentage removal at equilibrium was found to increase from $69.15 \%$ to $83.64 \%$ as the initial concentration of the dye was raised from $10 \mathrm{mg} / \mathrm{L}$ to $40 \mathrm{mg} / \mathrm{L}$. It can be seen from Tables-1, 2 and Figs. $-5,6$ that there is considerable increase in sorption capacity of $\mathrm{CCAC}-\mathrm{Fe}_{3} \mathrm{O}_{4}$ nanocomposite when compared to CCAC.

\section{Consequence of Contact Time}

The data presented in Tables-1, 2 and Figs.-5 and 6 also reveal that with an increase in contact time also, with both adsorbents, the percentage removal and sorption capacity increased. For example, taking 10 $\mathrm{mg} / \mathrm{L}$ initial concentration as specific example using nanocomposite as adsorbent, it can be seen that the percentage removal of MB raised from $60.53 \%$ to $81.56 \%$ (Table-4) with an increase in contact time.

When CCAC was used as an adsorbent, the experimental results in Tables-1, 2 and Fig. -5 and 6 reveal that with this adsorbent also the percentage removal and sorption capacity increased with contact time. 


\section{RASĀYAN J. Chem.}

Vol. 12 | No. 4 |2166 - 2175| October - December | 2019

However, the extent of removal was of lesser magnitude than in the case of nanocomposite. In this case of MB dye observed, it can be seen that the corresponding percentage of dye removal and sorption capacity had higher magnitude at any point of adsorption when $\mathrm{CCAC}-\mathrm{Fe}_{3} \mathrm{O}_{4}$ nanocomposite used as an adsorbent compared to CCAC.

Table-1: Consequence of Contact Time and Concentration of Dye

\begin{tabular}{c|c|c|c|c}
\hline \multirow{2}{*}{$\begin{array}{c}\text { Contact } \\
\text { Time, } \\
\mathrm{t}(\mathrm{min})\end{array}$} & \multicolumn{4}{|c}{$\mathrm{CCAC}+\mathrm{Fe}_{3} \mathrm{O}_{4} \mathrm{NANOCOMPOSITE}$} \\
\cline { 2 - 5 } & $10 \mathrm{mg} / \mathrm{L}$ & $20 \mathrm{mg} / \mathrm{L}$ & $30 \mathrm{mg} / \mathrm{L}$ & $40 \mathrm{mg} / \mathrm{L}$ \\
\hline 6 & $\begin{array}{c}\% \\
\text { Removal }\end{array}$ & $\begin{array}{c}\% \\
\text { Removal }\end{array}$ & $\begin{array}{c}\% \\
\text { Removal } \\
1\end{array}$ \\
\hline 12 & 60.53 & 76.28 & 80.70 & 84.20 \\
\hline 18 & 64.58 & 78.07 & 82.00 & 85.18 \\
\hline 24 & 73.20 & 82.30 & 84.45 & 88.12 \\
\hline 30 & 77.38 & 83.22 & 85.73 & 89.24 \\
\hline 36 & 80.49 & 84.29 & 87.00 & 89.57 \\
\hline 42 & 80.51 & 86.00 & 88.08 & 89.73 \\
\hline 48 & 80.70 & 87.65 & 89.60 & 91.50 \\
\hline 54 & 81.36 & 87.98 & 89.70 & 92.01 \\
\hline 60 & 81.56 & 88.00 & 90.63 & 93.34 \\
\hline
\end{tabular}

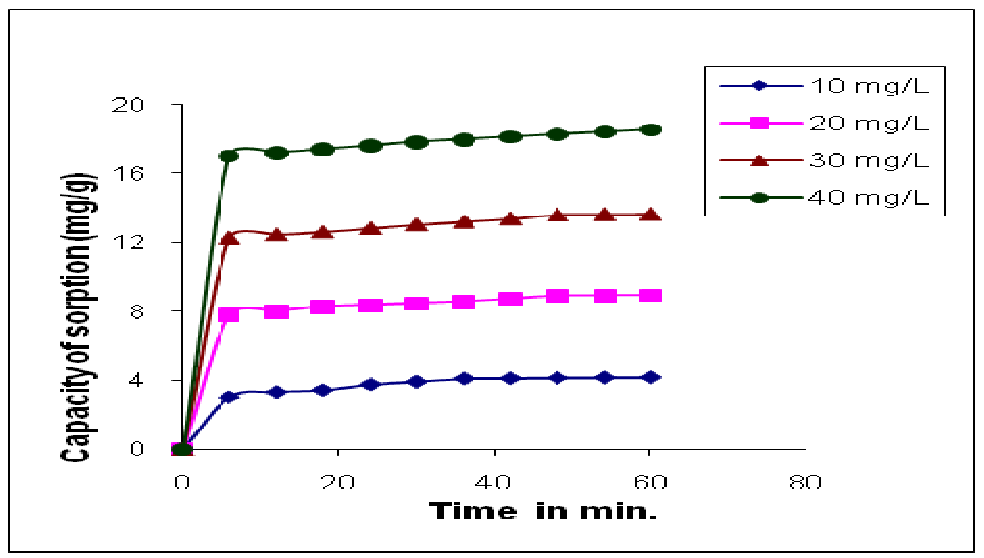

Fig.-5: $\mathrm{CCAC}+\mathrm{Fe}_{3} \mathrm{O}_{4}$ Nanocomposite [Methylene blue] Conditions: Dose of Adsorbent: $0.1 \mathrm{~g} / 50 \mathrm{~mL}$, Temp: $301 \mathrm{~K}$

\section{Consequence of the Adsorbent Dose}

To understand the consequence of different doses of adsorbent, the $50 \mathrm{~mL}$ solution of dye in different initial concentrations $(10,20,30$ and $40 \mathrm{mg} / \mathrm{L})$ were agitated with various amounts of both the adsorbents $\left(\mathrm{CCAC}+\mathrm{Fe}_{3} \mathrm{O}_{4}\right.$ nanocomposite \& CCAC) ranging from $0.1 \mathrm{~g}$ to $1 \mathrm{~g}$ for a time period is greater with equilibrium time. The flasks were taken and the contents were studied after separation. It can be inferred from the results depicted in Figs.-7 and 8 that in the case of MB dye studied, for a given concentration of dye solution, the amount percentage of displacement removal of dye raised with increase in adsorbent concentration, and reached a maximum with a particular weight of adsorbent and then remained constant with further addition of the adsorbent.

In the case of $\mathrm{MB}$, from the data in Tables-3 and 4 it can be observed that, for a solution of initial concentration of $10 \mathrm{mg} / \mathrm{L}$, the displacement per unit mass of the adsorbent for $\mathrm{MB}$ raised from $0.48 \mathrm{mg} / \mathrm{g}$ 


\section{RASĀYAN J. Chem.}

Vol. 12 | No. 4 |2166 - 2175| October - December | 2019

to $3.23 \mathrm{mg} / \mathrm{g}$ and then remained almost constant with further addition of adsorbent when the nanocomposite was the adsorbent.

Table-2: Consequence of Contact Time And Concentration of Dye

\begin{tabular}{c|c|c|c|c}
\hline \multirow{2}{*}{$\begin{array}{c}\text { Contact } \\
\text { Time, } \\
\mathrm{t}(\mathrm{min})\end{array}$} & \multicolumn{4}{|c}{ CCAC } \\
\cline { 2 - 5 } & $10 \mathrm{mg} / \mathrm{L}$ & $20 \mathrm{mg} / \mathrm{L}$ & $30 \mathrm{mg} / \mathrm{L}$ & $40 \mathrm{mg} / \mathrm{L}$ \\
\hline 6 & $\begin{array}{c}\% \\
\text { Removal }\end{array}$ & $\begin{array}{c}\% \\
\text { Removal } \\
\text { Removal }\end{array}$ & $\begin{array}{c}\% \\
\text { Removal }\end{array}$ \\
\hline 12 & 56.22 & 70.00 & 71.42 & 72.56 \\
\hline 18 & 60.43 & 71.75 & 74.02 & 75.80 \\
\hline 24 & 61.82 & 72.26 & 75.01 & 77.78 \\
\hline 30 & 62.27 & 73.67 & 76.21 & 78.66 \\
\hline 36 & 63.03 & 76.21 & 78.67 & 79.55 \\
\hline 42 & 64.82 & 78.06 & 79.20 & 80.00 \\
\hline 48 & 66.72 & 79.27 & 80.70 & 81.73 \\
\hline 54 & 68.06 & 80.27 & 82.31 & 82.75 \\
\hline 60 & 69.15 & 81.39 & 83.00 & 83.64 \\
\hline
\end{tabular}

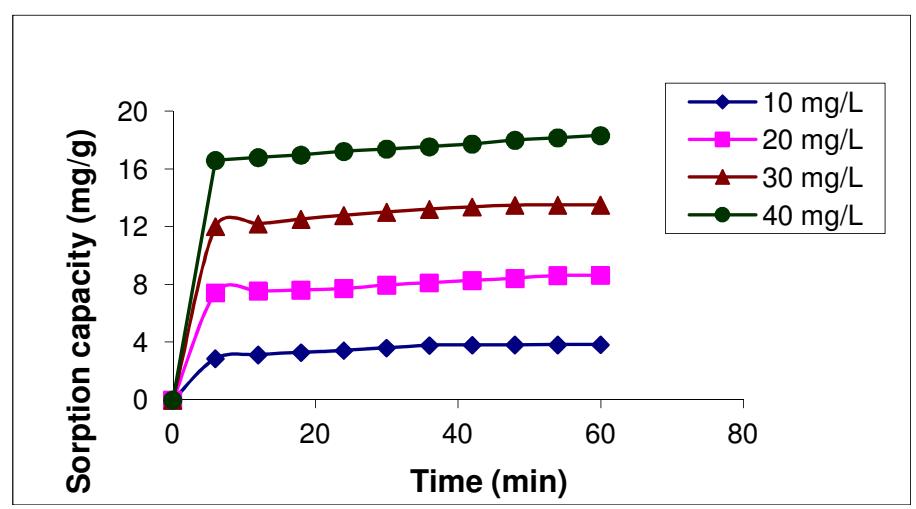

Fig.-6: CCAC[Methylene blue] Conditions: Dose of Adsorbent: $0.1 \mathrm{~g} / 50 \mathrm{~mL}$, Temp: 301K

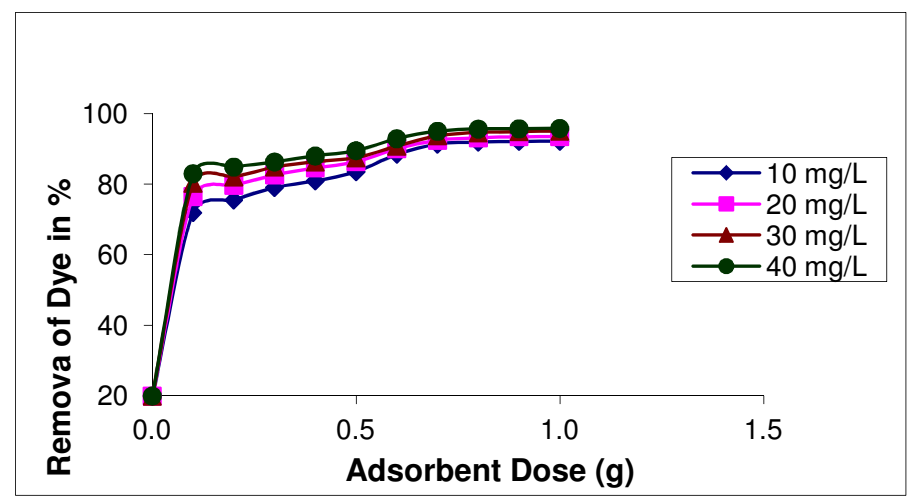

Fig.-7: $\mathrm{CCAC}+\mathrm{Fe}_{3} \mathrm{O}_{4}$ Nanocomposite [Methylene blue] Conditions: Adsorbate: $50 \mathrm{~mL}$, Agitation time: $1 \mathrm{hr}$, Temp: $301 \mathrm{~K}$

Table-3: Consequence of Adsorbent Dose

\begin{tabular}{|c|c|c|c|c|}
\hline \multirow{3}{*}{$\begin{array}{c}\text { Adsorbent } \\
\text { dose }(\mathrm{g})\end{array}$} & \multicolumn{4}{|c|}{$\mathrm{CCAC}+\mathrm{Fe}_{3} \mathrm{O}_{4} \mathrm{NANOCOMPOSITE}$} \\
\hline & $10 \mathrm{mg} / \mathrm{L}$ & $20 \mathrm{mg} / \mathrm{L}$ & $30 \mathrm{mg} / \mathrm{L}$ & $40 \mathrm{mg} / \mathrm{L}$ \\
\hline & $\begin{array}{c}\text { Capacity of } \\
\text { Sorption } \\
(\mathrm{mg} / \mathrm{g})\end{array}$ & $\begin{array}{c}\text { Capacity of } \\
\text { Sorption } \\
(\mathrm{mg} / \mathrm{g})\end{array}$ & $\begin{array}{c}\text { Capacity of } \\
\text { Sorption } \\
(\mathrm{mg} / \mathrm{g})\end{array}$ & $\begin{array}{c}\text { Capacity of } \\
\text { Sorption } \\
(\mathrm{mg} / \mathrm{g})\end{array}$ \\
\hline
\end{tabular}




\section{RASĀYAN J. Chem.}

Vol. 12 | No. 4 |2166 - 2175| October - December | 2019

\begin{tabular}{c|c|c|c|c}
\hline 0.1 & 0.48 & 0.99 & 1.35 & 1.77 \\
\hline 0.2 & 0.5 & 1.11 & 1.59 & 1.97 \\
\hline 0.3 & 0.55 & 1.2 & 1.76 & 2.52 \\
\hline 0.4 & 0.59 & 1.29 & 1.96 & 2.84 \\
\hline 0.5 & 0.79 & 1.53 & 2.12 & 3.22 \\
\hline 0.6 & 0.85 & 1.98 & 2.76 & 4.54 \\
\hline 0.7 & 0.89 & 2.08 & 3.27 & 5.37 \\
\hline 0.8 & 1.18 & 2.9 & 4.24 & 6.71 \\
\hline 0.9 & 1.55 & 4.12 & 5.11 & 7.38 \\
\hline 1.0 & 3.23 & 6.68 & 11.05 & 14.51 \\
\hline
\end{tabular}

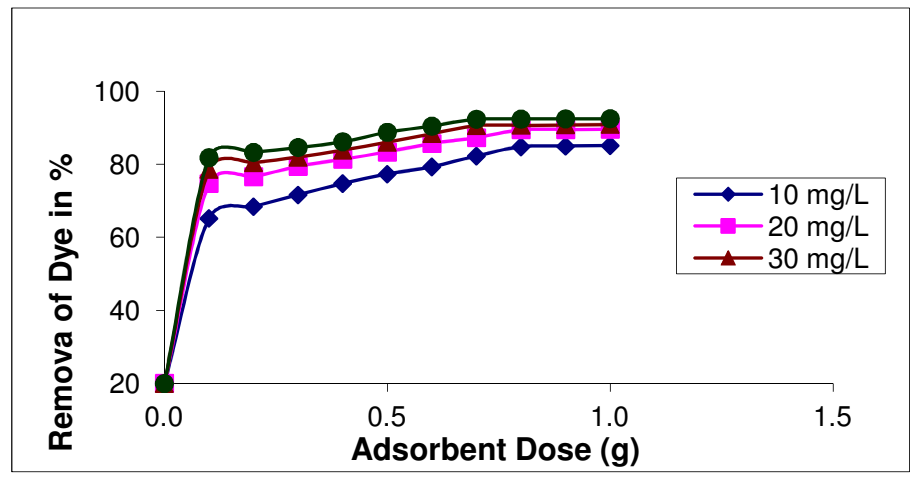

Fig.-8: CCAC[Methylene blue] Conditions: Adsorbate: $50 \mathrm{~mL}$, Agitation time: $1 \mathrm{hr}$, Temp: 301K

\section{Removal of Methylene Blue Using $\mathrm{CCAC}-\mathrm{Fe}_{3} \mathrm{O}_{4}$ Nanocomposite Consequence of $\mathbf{p H}$}

Displacement experiments were carried out separately using different concentrations of MB dye solutions $(10 \mathrm{mg} / \mathrm{L}, 20 \mathrm{mg} / \mathrm{L}, 30 \mathrm{mg} / \mathrm{L}, 40 \mathrm{mg} / \mathrm{L})$ at various $\mathrm{pH}$ values ranging from 5 to 11 with the fixed adsorbent concentration $(100 \mathrm{mg} / 50 \mathrm{~mL})$ maintaining the required $\mathrm{pH}$ by adding necessary amount of $0.001 \mathrm{M}$ dilute hydrochloric acid and $0.001 \mathrm{M}$ sodium hydroxide solutions.

It can be observed from the data given in Tables-5, 6 and Figs.-9, 10 that with a rise in $\mathrm{pH}$ of the solution the percent of removal and sorption capacity increased up to a certain $\mathrm{pH}$ value. Further increase beyond this $\mathrm{pH}$ value had no notable effect on the rate of adsorption. In the case of $\mathrm{MB}$ as a representative example, the data in Table- 5 shows that for a solution of concentration $10 \mathrm{mg} / \mathrm{L}$ with a fixed dose of the adsorbent, the $\mathrm{pH}$ increased from 5-11, as well as the percent of removal of MB increased from $62.91 \%$ to $78.76 \%$ when the nanocomposite was the adsorbent. Under identical conditions when CCAC was the adsorbent, the increase observed was from $48.83 \%$ to $72.49 \%$.

\begin{tabular}{c|c|c|c|c}
\multicolumn{6}{c}{ Table-4: Consequence of Adsorbent Dose } \\
\cline { 2 - 5 } & \multicolumn{5}{c}{ CCAC } \\
\cline { 2 - 5 } $\begin{array}{c}\text { Adsorbent } \\
\text { dose }(\mathrm{g})\end{array}$ & $\begin{array}{c}\text { Capacity } \\
\text { of } \\
\text { Sorption } \\
(\mathrm{mg} / \mathrm{g})\end{array}$ & $\begin{array}{c}\text { Capacity } \\
\text { of } \\
\text { Sorption } \\
(\mathrm{mg} / \mathrm{g})\end{array}$ & $\begin{array}{c}\text { Capacity } \\
\text { of } \\
\text { Sorption } \\
(\mathrm{mg} / \mathrm{g})\end{array}$ & $\begin{array}{c}\text { Capacity } \\
\text { of } \\
\text { Sorption } \\
(\mathrm{mg} / \mathrm{g}))\end{array}$ \\
\hline 0.1 & 0.29 & 0.81 & 1.14 & 1.46 \\
\hline 0.2 & 0.36 & 0.98 & 1.31 & 1.71 \\
\hline 0.3 & 0.4 & 1 & 1.51 & 2.2 \\
\hline 0.4 & 0.47 & 1.11 & 1.71 & 2.5 \\
\hline 0.5 & 0.52 & 1.2 & 1.92 & 2.96 \\
\hline 0.6 & 0.61 & 1.22 & 2.46 & 3.46 \\
\hline
\end{tabular}


RASĀYAN J. Chem.

Vol. 12 | No. 4 |2166 - 2175| October - December | 2019

\begin{tabular}{c|c|c|c|c}
\hline 0.7 & 0.72 & 1.91 & 3.03 & 4.21 \\
\hline 0.8 & 0.91 & 2.6 & 4.01 & 5.51 \\
\hline 0.9 & 1.38 & 3.7 & 4.72 & 6.77 \\
\hline 1.0 & 2.78 & 6.22 & 6.32 & 9.69 \\
\hline
\end{tabular}

\section{Consequence of Temperature Variation}

In this experiment, $50 \mathrm{~mL}$ of $40 \mathrm{mg} / \mathrm{L}$ of $\mathrm{MB}$ solutions were added with $100 \mathrm{mg}$ of adsorbent (CCAC$\mathrm{Fe}_{3} \mathrm{O}_{4}$ nanocomposite \& CCAC) separately and agitated in a thermostatic water bath at the desired temperatures $(303 \mathrm{~K}, 307 \mathrm{~K}, 311 \mathrm{~K}$ and $315 \mathrm{~K})$. The solutions were taken at particular intervals, separated and analyzed by using a spectrophotometer. The results of the experiments on the effect of contact time and temperature on the displacement of dyes by both adsorbents were plotted in Figs.-11, 12 and the corresponding data were presented in Tables-7, 8 for all the dyes studied. In the case of MB, the percent removal decreased from 98.91 to $95.25 \%$ with nanocomposite(Table-7) and from $96.74 \%$ to $94.06 \%$ (Table-8) with CCAC as the temperature increased from $303 \mathrm{~K}$ to $315 \mathrm{~K}$.

Table-5: Consequence of $\mathrm{pH}$

\begin{tabular}{c|c|c|c|c}
\hline \multirow{2}{*}{$\mathrm{pH}$} & \multicolumn{4}{|c}{$\mathrm{CAC}+\mathrm{Fe}_{3} \mathrm{O}_{4} \mathrm{NANOCOMPOSITE}$} \\
\cline { 2 - 5 } & $10 \mathrm{mg} / \mathrm{L}$ & $20 \mathrm{mg} / \mathrm{L}$ & $30 \mathrm{mg} / \mathrm{L}$ & $40 \mathrm{mg} / \mathrm{L}$ \\
\cline { 2 - 5 } & $\begin{array}{c}\% \\
\text { Removal }\end{array}$ & $\begin{array}{c}\% \\
\text { Removal }\end{array}$ & $\begin{array}{c}\% \\
\text { Removal }\end{array}$ & $\begin{array}{c}\% \\
\text { Removal }\end{array}$ \\
\hline 5.0 & 62.91 & 75.82 & 82.53 & 83.90 \\
\hline 5.5 & 65.67 & 77.40 & 83.48 & 85.12 \\
\hline 6.0 & 67.89 & 78.90 & 84.46 & 85.79 \\
\hline 6.5 & 70.09 & 80.10 & 85.44 & 86.47 \\
\hline 7.0 & 72.82 & 81.20 & 86.31 & 87.30 \\
\hline 7.5 & 75.70 & 83.22 & 87.01 & 88.18 \\
\hline 8.0 & 76.02 & 84.60 & 88.24 & 90.00 \\
\hline 8.5 & 76.20 & 85.20 & 89.35 & 90.11 \\
\hline 9.0 & 76.59 & 85.98 & 90.46 & 91.69 \\
\hline 9.5 & 76.76 & 86.40 & 90.54 & 92.50 \\
\hline 10.0 & 77.00 & 86.56 & 90.63 & 93.61 \\
\hline 10.5 & 77.16 & 87.14 & 90.73 & 93.72 \\
\hline 11.0 & 78.76 & 88.70 & 90.79 & 93.78 \\
\hline
\end{tabular}

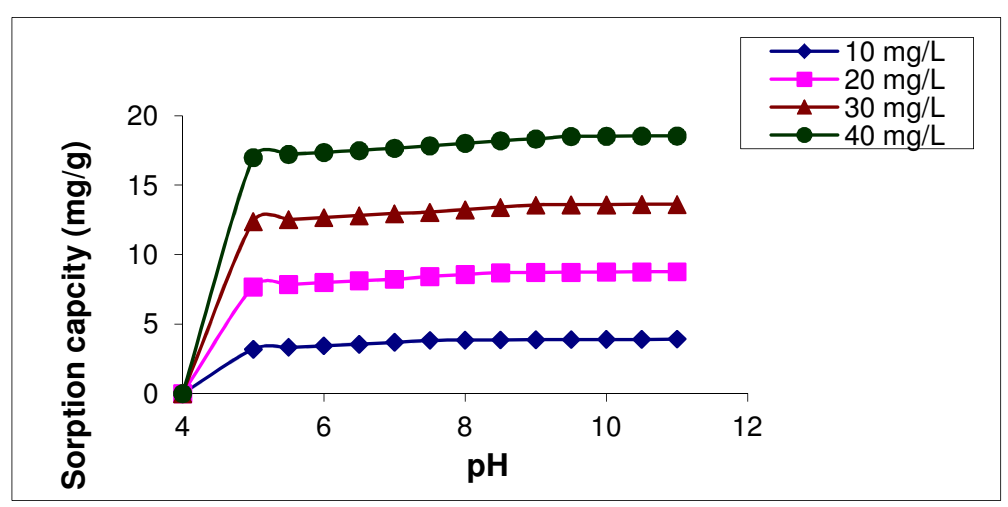

Fig.-9: $\mathrm{CCAC}+\mathrm{Fe}_{3} \mathrm{O}_{4}$ Nanocomposite [Methylene blue] Conditions: Agitation time: $1.5 \mathrm{hr}$, Adsorbentdose: $0.1 \mathrm{~g} / 50 \mathrm{~mL}$, Temp: $301 \mathrm{~K}$

Table -6: Consequence of $\mathrm{pH}$

\begin{tabular}{c|c|c|c|c}
\hline \multirow{4}{*}{$\mathrm{pH}$} & \multicolumn{4}{|c}{ CCAC } \\
\cline { 2 - 5 } & $10 \mathrm{mg} / \mathrm{L}$ & $20 \mathrm{mg} / \mathrm{L}$ & $30 \mathrm{mg} / \mathrm{L}$ & $40 \mathrm{mg} / \mathrm{L}$ \\
\cline { 2 - 5 } & $\begin{array}{c}\% \\
\text { Removal }\end{array}$ & $\begin{array}{c}\% \\
\text { Removal }\end{array}$ & $\begin{array}{c}\% \\
\text { Removal }\end{array}$ & Removal \\
\hline
\end{tabular}


RASĀYAN J. Chem.

Vol. 12 | No. 4 |2166 - 2175| October - December | 2019

\begin{tabular}{c|c|c|c|c}
\hline 5.0 & 48.83 & 69.16 & 76.10 & 78.91 \\
\hline 5.5 & 51.65 & 70.45 & 77.09 & 80.27 \\
\hline 6.0 & 54.42 & 71.20 & 78.11 & 81.16 \\
\hline 6.5 & 58.66 & 73.99 & 79.75 & 82.32 \\
\hline 7.0 & 62.57 & 76.09 & 80.87 & 83.10 \\
\hline 7.5 & 65.18 & 77.23 & 81.60 & 83.18 \\
\hline 8.0 & 68.35 & 78.58 & 82.61 & 85.20 \\
\hline 8.5 & 68.60 & 79.25 & 83.30 & 85.90 \\
\hline 9.0 & 68.84 & 80.37 & 84.61 & 86.12 \\
\hline 9.5 & 69.01 & 81.49 & 84.70 & 87.13 \\
\hline 10.0 & 70.33 & 81.56 & 84.81 & 88.21 \\
\hline 10.5 & 71.66 & 82.14 & 85.21 & 89.24 \\
\hline 11.0 & 72.49 & 84.69 & 85.79 & 88.78 \\
\hline
\end{tabular}

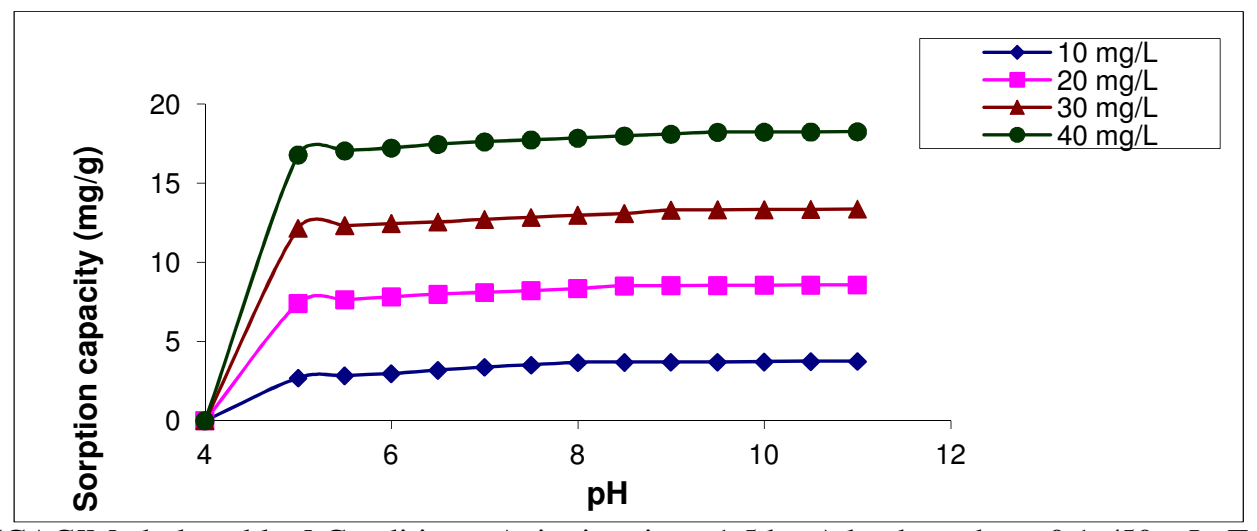

Fig.-10: CCAC[Methylene blue] Conditions: Agitation time: $1.5 \mathrm{hr}$, Adsorbent dose: $0.1 \mathrm{~g} / 50 \mathrm{~mL}$, Temp: $301 \mathrm{~K}$

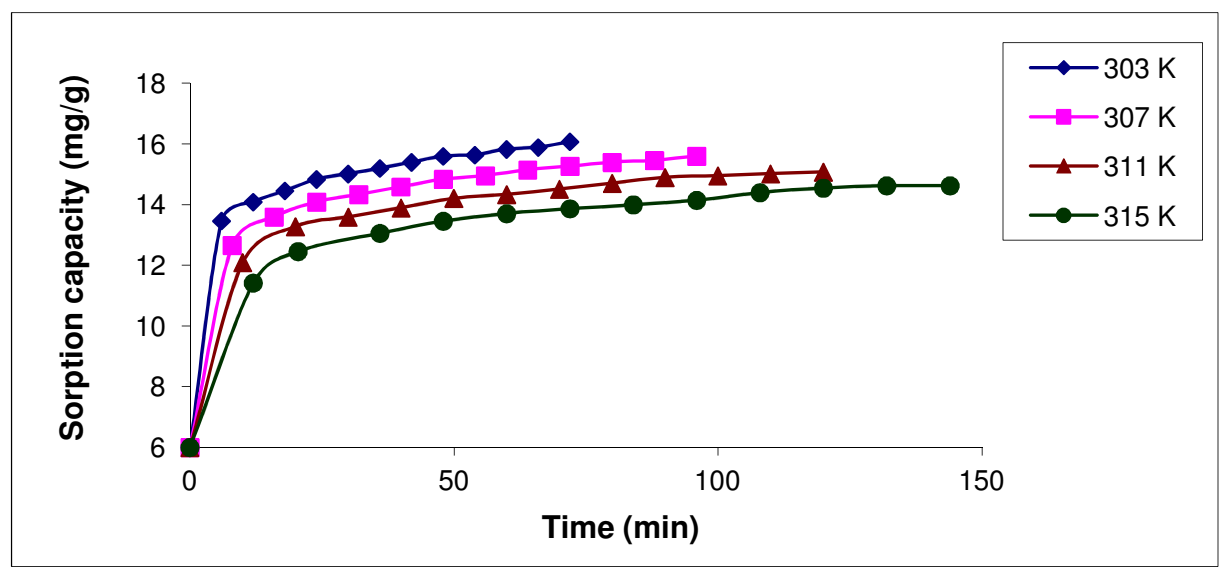

Fig.-11: $\mathrm{CCAC}+\mathrm{Fe}_{3} \mathrm{O}_{4}$ Nanocomposite [Methylene blue] Conditions: Adsorbent dose: $0.1 \mathrm{~g} / 50 \mathrm{~mL}$, Dye concentration: $40 \mathrm{mg} / \mathrm{L}$

Table-7: Consequence of Temperature

\begin{tabular}{c|c|c|c|c|c|c|c}
\hline \multicolumn{2}{c|}{$303 \mathrm{~K}$} & \multicolumn{2}{c|}{$307 \mathrm{~K}$} & \multicolumn{2}{c|}{$311 \mathrm{~K}$} & \multicolumn{2}{c}{$315 \mathrm{~K}$} \\
\hline $\begin{array}{c}\text { Contact } \\
\text { Time, }(\mathrm{t}) \text { in } \\
\text { min }\end{array}$ & \% Removal & $\begin{array}{c}\text { Contact } \\
\text { Time, }(\mathrm{t}) \text { in } \\
\text { min }\end{array}$ & $\begin{array}{c}\% \\
\text { Removal }\end{array}$ & $\begin{array}{c}\text { Contact } \\
\text { Time, }(\mathrm{t}) \text { in } \\
\text { min }\end{array}$ & $\begin{array}{c}\% \\
\text { Removal }\end{array}$ & $\begin{array}{c}\text { Contact } \\
\text { Time, }(\mathrm{t}) \text { in } \\
\text { min }\end{array}$ & $\begin{array}{c}\% \\
\text { Removal }\end{array}$ \\
\hline 6 & 89.26 & 8 & 87.60 & 10 & 85.30 & 12 & 84.01 \\
\hline 12 & 91.22 & 16 & 90.58 & 20 & 86.40 & 24 & 84.61 \\
\hline 18 & 91.78 & 24 & 91.72 & 30 & 90.26 & 36 & 86.28 \\
\hline 24 & 93.43 & 32 & 92.58 & 40 & 91.82 & 48 & 87.77 \\
\hline
\end{tabular}

ACTIVATED CARBON $+\mathrm{Fe}_{3} \mathrm{O}_{4}$ NANOCOMPOSITE 
RASĀYAN J. Chem.

Vol. 12 | No. 4 |2166 - 2175| October - December | 2019

\begin{tabular}{l|l|l|l|l|l|l|l}
\hline 30 & 94.70 & 40 & 93.72 & 50 & 93.33 & 60 & 90.64 \\
\hline 36 & 95.92 & 48 & 94.84 & 60 & 93.92 & 72 & 91.42 \\
\hline 42 & 96.65 & 56 & 95.14 & 70 & 94.04 & 84 & 92.89 \\
\hline 48 & 96.78 & 64 & 95.96 & 80 & 94.92 & 96 & 93.99 \\
\hline 54 & 97.85 & 82 & 96.18 & 90 & 95.06 & 108 & 94.07 \\
\hline 60 & 98.91 & 80 & 97.24 & 100 & 96.16 & 120 & 95.25 \\
\hline
\end{tabular}

Table-8: Consequence of Temperature

\begin{tabular}{c|c|c|c|c|c|c|c}
\hline \multicolumn{2}{c|}{$303 \mathrm{~K}$} & \multicolumn{2}{c|}{$307 \mathrm{~K}$} & \multicolumn{2}{c}{$311 \mathrm{~K}$} & \multicolumn{2}{c}{$315 \mathrm{~K}$} \\
\hline $\begin{array}{c}\text { Contact } \\
\begin{array}{c}\text { Time, (t) in } \\
\text { min }\end{array}\end{array}$ & $\begin{array}{c}\text { Contact } \\
\text { Removal }\end{array}$ & $\begin{array}{c}\text { Time, }(\mathrm{t}) \text { in } \\
\text { min }\end{array}$ & $\begin{array}{c}\% \\
\text { Removal } \\
\text { Time, }(\mathrm{t}) \text { in } \\
\text { min }\end{array}$ & $\begin{array}{c}\text { Contact } \\
\text { Time }(\mathrm{t}) \text { in } \\
\text { min }\end{array}$ & $\begin{array}{c}\% \\
\text { Removal }\end{array}$ \\
\hline 6 & 89.79 & 8 & 88.34 & 10 & 86.69 & 12 & 84.72 \\
\hline 12 & 90.56 & 16 & 89.18 & 20 & 87.75 & 24 & 87.14 \\
\hline 18 & 91.81 & 24 & 90.36 & 30 & 89.44 & 36 & 87.63 \\
\hline 24 & 92.30 & 32 & 92.26 & 40 & 90.58 & 48 & 88.61 \\
\hline 30 & 93.86 & 40 & 93.68 & 50 & 92.21 & 60 & 90.36 \\
\hline 36 & 94.33 & 48 & 94.13 & 60 & 92.44 & 72 & 91.68 \\
\hline 42 & 95.89 & 56 & 95.70 & 70 & 94.96 & 84 & 93.18 \\
\hline 48 & 96.53 & 64 & 96.13 & 80 & 95.72 & 96 & 93.80 \\
\hline 54 & 96.64 & 82 & 96.23 & 90 & 96.07 & 108 & 93.97 \\
\hline 60 & 96.74 & 80 & 96.33 & 100 & 96.19 & 120 & 94.06 \\
\hline
\end{tabular}

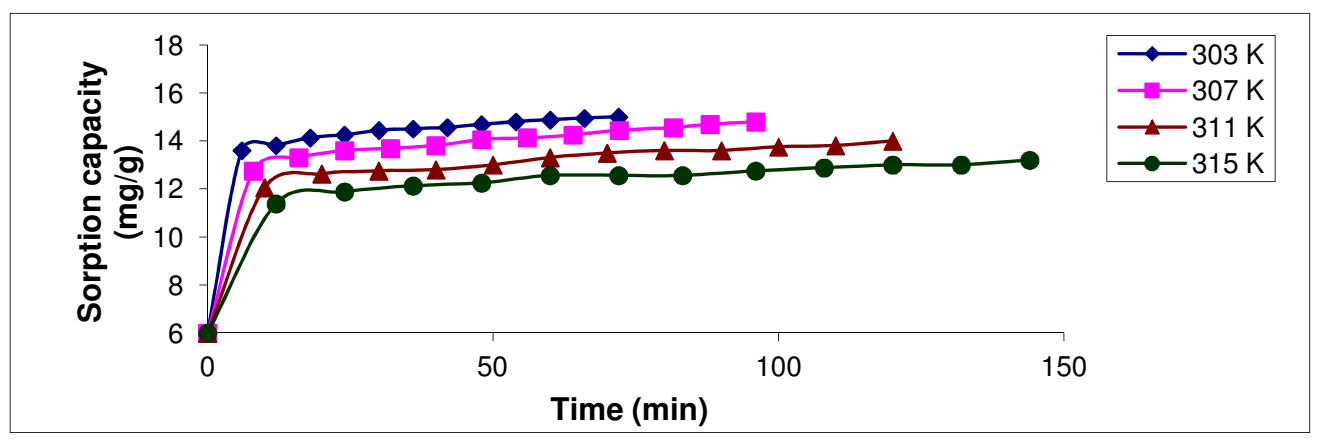

Fig.-12: CCAC[Methylene blue] Conditions: Adsorbent dose: $0.1 \mathrm{~g} / 50 \mathrm{~mL}$, Dye concentration: $40 \mathrm{mg} / \mathrm{L}$

\section{CONCLUSION}

The batch adsorption studies were performed to find out the impact of agitation time, beginning concentration $(10, \quad 20, \quad 30, \quad \& \quad 40 \mathrm{mg} / \mathrm{L})$, adsorbent dose $(0.1$ to $1.0 \mathrm{~g})$, initial $\mathrm{pH}(5-11)$ and temperature $(303 \mathrm{~K}, 307 \mathrm{~K}, 311 \mathrm{~K}$ and $315 \mathrm{~K})$ on the dye utilizing both nanocomposite and CCAC.The investigation on the impact of concentration of dye displacement of MB and agitation time on the quantity of $\mathrm{MB}$ dye displaced demonstrated that the agitation time increased the amount of dye displaced per unit mass of the adsorbent also increased and the amount of dye displaced per unit weight of the adsorbent attained a steady state of dynamic equilibrium after certain time.

An increase in percent removal was observed with an increase in adsorbent dose. The investigation on the impact of the initial $\mathrm{p}^{\mathrm{H}}$ of $\mathrm{MB}$ dye solutions on the adsorption process revealed that an increase in initial $\mathrm{p}^{\mathrm{H}}$ of dye solutions increased the effective removal of the two adsorbents up to a specific $\mathrm{p}^{\mathrm{H}}$.

The curves obtained from the beginning concentration of dye and contact time shown were continuous, single and smooth which lead to saturation suggest the possible monolayer coverage of dye onto the adsorbent surface. The decrease in the percent of uptake of the dye with the rise in temperature revealed the exothermic type of displacement reaction. The fact that better removal of MB dye occurred for basic dye at alkaline $\mathrm{pH}$ suggested that the displacement may be chemisorptive nature.

From all the data obtained from the effect of contact time, beginning concentration, adsorbent dose, $\mathrm{pH}$ and temperature, in the case of $\mathrm{MB}$ dye studied, the amount of displacement of dye from aqueous 
RASĀYAN J. Chem.

Vol. 12 | No. 4 |2166 - 2175| October - December | 2019

solutions had a lesser magnitude when the CCAC was used as the adsorbent compared with the CCAC$\mathrm{Fe}_{3} \mathrm{O}_{4}$ nanocomposite.

\section{REFERENCES}

1. Mahalakshmi Mathivanan and Saranaathan S.E, Rasayan Journal of Chemistry,11, 877(2018), DOI:10.37188/RJC.2018.1122086.

2. Puthiya Veetil Nidheesh, Rajan Gandhimathi, Sreekrishnaperumal Thanga Ramesh and Tangappan Sarasvathy Anantha Singh, Journal of Urban and Environmental Engineering.,6,18(2012), DOI: 10.4090/juee.2012.v6n1.018029.

3. Raffiea Baseri, P.N. Palanisamy and P. Sivakumar, E-Journal of Chemistry., 9, 1122(2012), DOI: $10.1155 / 2012 / 603196$.

4. P. Pallavi, P. King and Y. Prasanna Kumar, Rasayan Journal of Chemistry,11, 203(2018), DOI:10.7324/RJC.2018.1111971.

5. Khalid M. Mousa, Alaa H. Taha, Petroleum Science and Engineering., 2, 17(2017), DOI:10.11648/j.pse.20170201.14.

6. Snehal Yedurkar, Chandra Maurya, Prakash Mahanwar, Open Journal of Synthesis Theory and Application., 5, 1(2016), DOI: 10.4236/ojsta.2016.51001.

7. K. Venkata Ramana, K. Swarna Latha , K. Ravindranath and B. Hari Babu, Rasayan Journal of Chemistry, 10, 349(2017), DOI: 10.7324/RJC.2017.1021537.

8. Yash Mishra, V. Sowmya and S. Shanthakumar, Journal of Urban and EnvironmentalEngineering.,9, 102(2015), DOI: 10.4090/juee.2015.v9n2.102108.

9. Rajvir Kaur and Harpreet Kaur, Asian Journal of Chemistry, 29, 441(2017), DOI:10.14233/ajchem.2017.20242.

10. Lin SH, Juang RS., A Review. J Environ Manage., 90, 1336(2009), DOI:10.1016/j.jenvman.2008.09.003.

11. Shokoohi R, Vatanpoor V, Zarrabi M, Vatani A., E-Journal of Chem.,7, 65 (2010), DOI:10.1155/2010/958073.

12. W.Astuti,T.Sulistyaningsih and M.Makshola, Asian Journal of Chemistry, 29, 133(2017), DOI:10.14233/ajchem.2017.20158.

13. Yantus A.B Neolaka, Eka B.S Kalla, Gusti A. Malelak, Nia K. Rukman, Ganden Supriyanto and Ni Nyoman Tri Puspaningsih, Rasayan Journal of Chemistry, 11, 494(2018), DOI: 10.37188/RJC.2018.1121994.

14. Jiao Chen and Julia Xiaojun Zhao, 12, 2414(2012), DOI:10.3390/s120302414.

15. G. Velraj, K. Janaki, A.M. Musthafa and R. Palanivel, Applied Clay Science, 43(3-4), 303(2009), DOI:10.1016/j.clay.2008.09.005

[RJC-5181/2019] 